\title{
Editorial
}

Clinical Care/Education

Diabetes Metab J 2014;38:32-34

http://dx.doi.org/10.4093/dmj.2014.38.1.32

pISSN 2233-6079 • eISSN 2233-6087

DIABET\&S\& M ETABOLISM JOURNAL

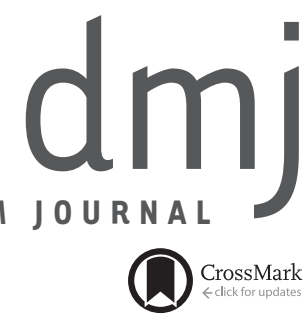

\section{Statin for the Primary Prevention of Cardiovascular Disease in Patients with Diabetes Mellitus}

\author{
Bo Kyung Koo ${ }^{1,2}$ \\ ${ }^{1}$ Department of Internal Medicine, Boramae Medical Center, Seoul National University College of Medicine, Seoul, \\ ${ }^{2}$ Department of Internal Medicine, Seoul National University College of Medicine, Seoul, Korea
}

Stain is commonly used in subjects with diabetes for both primary and secondary prevention of cardiovascular diseases (CVDs) [1,2]. It is even recommended by the American Diabetes Association to be added to lifestyle therapy regardless of the baseline lipid levels for diabetic patients aged $\geq 40$ years, even if they have no overt CVD [3], and recent guidelines from the American College of Cardiology and the American Heart Association states that statin therapy should be initiated and maintained for the primary prevention for CVD in adults 40 to 75 years of age with diabetes mellitus, regardless of their CVD risk if their low density lipoprotein cholesterol (LDL-C) level is $\geq 70 \mathrm{mg} / \mathrm{dL}$ [4].

The possibility of primary prevention of CVD with statin therapy for diabetic subjects with a high CVD risk has been well elucidated $[1,5,6]$. Collaborative Atorvastatin Diabetes Study (CARDS) [1] was a large randomized controlled trial aimed to show the efficacy of statin for the primary prevention of CVD in subjects with type 2 diabetes who had at least one or more of CVD risk factors, but the study terminated 2 years earlier than expected. This was because the statin group showed a superior risk reduction than expected: CVD event reduction of $37 \%$ (95\% confidence interval [CI], -52 to -17 ) in statin group [1]. However, there are still insufficient evidence to show the effect of statin for the primary prevention of CVD in diabetic patients with a low risk.

There have been claims that statins should be used with caution for the primary prevention in subjects with low CVD risk $[7,8]$. Furthermore, statin therapy has been reported to be associated with myopathy, elevated liver enzyme concentration, and incident diabetes mellitus $[9,10]$. However, recent metaanalysis of Cholesterol Treatment Trialists' (CTT) collaborators showed an overall relative risk reduction of major vascular events of $21 \%$ (relative risk, $0.79 ; 95 \%$ CI, 0.77 to 0.81 ) per 1 $\mathrm{mmol} / \mathrm{L}$ reduction of LDL-C with statin; these benefits were similar in people with a lower CVD risk [11]. Subjects with less than $5 \%$ of CVD risk also showed a significant risk reduction of about $40 \%$ per $1 \mathrm{mmol} / \mathrm{L}$ reduction of LDL-C with statin [11]. In addition, Justification for Use of statins in Prevention: an Intervention Trial Evaluating Rosuvastatin (JUPITER) [12] showed that statin decreased the rate of CVD in healthy men and women with LDL-C level $\leq 130 \mathrm{mg} / \mathrm{dL}$.

Although CTT and JUPITER was not performed exclusively in diabetic patients, their results might be implicated with diabetic subjects with a low CVD risk. Moreover, diabetes is an important risk factor for CVD and is considered as an equivalent to coronary artery disease [13]. Reductions in CVD outcomes were greatest in people with high baseline CVD risk [10]. Nonetheless, subgroup analysis from the meta-analysis of CTT reported that statin could reduce CVD events in subjects with diabetes regardless of their baseline CVD risk or baseline LDL-C [6].

Lee et al. [14] reported that statin discontinuation could be considered based on the pretreatment lipid profiles, especially for subjects with baseline LDL-C less than $123 \mathrm{mg} / \mathrm{dL}$. How-
Corresponding author: Bo Kyung Koo

Department of Internal Medicine, Boramae Medical Center,

Seoul National University College of Medicine, 20 Boramae-ro 5-gil,

Dongjak-gu, Seoul 156-707, Korea

E-mail: bokyungkoomd@gmail.com
This is an Open Access article distributed under the terms of the Creative Commons Attribution Non-Commercial License (http://creativecommons.org/licenses/by-nc/3.0/) which permits unrestricted non-commercial use, distribution, and reproduction in any medium, provided the original work is properly cited. 
ever, considering that statin therapy is not for reducing LDL-C itself but for reducing CVD risk, their results should be interpreted carefully to make the decision whether statin should be continued or not. As the authors mentioned, the effect of stopping statin on future CVD risk in diabetic patients with a low CVD risk remains to be elucidated.

There have been obvious concerns on the cost-effectiveness of primary prevention of CVD with statin in diabetic subjects with a low CVD risk. CARDS applied the United Kingdom Prospective Diabetes Study risk engine for their study population to predict the probability of a CVD event for each CARDS patient and showed that the incremental cost-effectiveness ratio was $£ 5,983$ per event-free year for subjects with a low CVD risk and $£ 2,077$ per event-free year for subjects with a high CVD risk [15]. In addition, other issues such as feasibility and desirability should be considered to treat the majority of diabetic patients aged $\geq 40$ years and the role of alternative public health strategies to lower blood cholesterol.

In conclusion, the use of statins for the primary prevention in diabetic subjects with a low CVD risk remains suspensive in its cost-effectiveness. Considering the high risk of CVD in diabetic patients compared to non-diabetic individuals, further studies to elucidate whether statin therapy should be started and maintained for diabetic subjects with a low CVD risk should be performed.

\section{CONFLICTS OF INTEREST}

No potential conflict of interest relevant to this article was reported.

\section{REFERENCES}

1. Colhoun HM, Betteridge DJ, Durrington PN, Hitman GA, Neil HA, Livingstone SJ, Thomason MJ, Mackness MI, Charlton-Menys V, Fuller JH; CARDS investigators. Primary prevention of cardiovascular disease with atorvastatin in type 2 diabetes in the Collaborative Atorvastatin Diabetes Study (CARDS): multicentre randomised placebo-controlled trial. Lancet 2004;364:685-96.

2. Pyorala K, Pedersen TR, Kjekshus J, Faergeman O, Olsson AG, Thorgeirsson G. Cholesterol lowering with simvastatin improves prognosis of diabetic patients with coronary heart disease. A subgroup analysis of the Scandinavian Simvastatin Survival Study (4S). Diabetes Care 1997;20:614-20.
3. American Diabetes Association. Standards of medical care in diabetes: 2014. Diabetes Care 2014;37 Suppl 1:S14-80.

4. Stone NJ, Robinson J, Lichtenstein AH, Bairey Merz CN, Lloyd-Jones DM, Blum CB, McBride P, Eckel RH, Schwartz JS, Goldberg AC, Shero ST, Gordon D, Smith SC Jr, Levy D, Watson K, Wilson PW. 2013 ACC/AHA guideline on the treatment of blood cholesterol to reduce atherosclerotic cardiovascular risk in adults: a report of the American College of Cardiology/American Heart Association Task Force on Practice Guidelines. J Am Coll Cardiol. Epub 2013 Nov 7. http://dx.doi. org/10.1016/j.jacc.2013.11.002.

5. Collins R, Armitage J, Parish S, Sleigh P, Peto R; Heart Protection Study Collaborative Group. MRC/BHF Heart Protection Study of cholesterol-lowering with simvastatin in 5963 people with diabetes: a randomised placebo-controlled trial. Lancet 2003;361:2005-16.

6. Cholesterol Treatment Trialists' (CTT) Collaborators, Kearney PM, Blackwell L, Collins R, Keech A, Simes J, Peto R, Armitage J, Baigent C. Efficacy of cholesterol-lowering therapy in 18,686 people with diabetes in 14 randomised trials of statins: a metaanalysis. Lancet 2008;371:117-25.

7. Ray KK, Seshasai SR, Erqou S, Sever P, Jukema JW, Ford I, Sat$\operatorname{tar}$ N. Statins and all-cause mortality in high-risk primary prevention: a meta-analysis of 11 randomized controlled trials involving 65,229 participants. Arch Intern Med 2010;170:1024-31.

8. Taylor F, Ward K, Moore TH, Burke M, Davey Smith G, Casas JP, Ebrahim S. Statins for the primary prevention of cardiovascular disease. Cochrane Database Syst Rev 2011;1:CD004816.

9. Carter AA, Gomes T, Camacho X, Juurlink DN, Shah BR, Mamdani MM. Risk of incident diabetes among patients treated with statins: population based study. BMJ 2013;346:f2610.

10. Taylor F, Huffman MD, Macedo AF, Moore TH, Burke M, Davey Smith G, Ward K, Ebrahim S. Statins for the primary prevention of cardiovascular disease. Cochrane Database Syst Rev 2013;1:CD004816.

11. Cholesterol Treatment Trialists' (CTT) Collaborators, Mihaylova B, Emberson J, Blackwell L, Keech A, Simes J, Barnes EH, Voysey M, Gray A, Collins R, Baigent C. The effects of lowering LDL cholesterol with statin therapy in people at low risk of vascular disease: meta-analysis of individual data from 27 randomised trials. Lancet 2012;380:581-90.

12. Ridker PM, Danielson E, Fonseca FA, Genest J, Gotto AM Jr, Kastelein JJ, Koenig W, Libby P, Lorenzatti AJ, MacFadyen JG, Nordestgaard BG, Shepherd J, Willerson JT, Glynn RJ; JUPITER Study Group. Rosuvastatin to prevent vascular events in 
men and women with elevated C-reactive protein. $\mathrm{N}$ Engl J Med 2008;359:2195-207.

13. Haffner SM, Lehto S, Ronnemaa T, Pyorala K, Laakso M. Mortality from coronary heart disease in subjects with type 2 diabetes and in nondiabetic subjects with and without prior myocardial infarction. N Engl J Med 1998;339:229-34.

14. Lee SH, Kwon HS, Park YM, Ko SH, Choi YH, Yoon KH, Ahn YB. Statin discontinuation after achieving a target low density lipoprotein cholesterol level in type 2 diabetic patients without cardiovascular disease: a randomized controlled study. Diabetes Metab J 2014;38:64-73.

15. Raikou M, McGuire A, Colhoun HM, Betteridge DJ, Durrington PN, Hitman GA, Neil HA, Livingstone SJ, Charlton-Menys V, Fuller JH; CARDS Investigators. Cost-effectiveness of primary prevention of cardiovascular disease with atorvastatin in type 2 diabetes: results from the Collaborative Atorvastatin Diabetes Study (CARDS). Diabetologia 2007;50:733-40. 